\title{
Evidence of co-parasitism between different species of chiggers (Trombidiformes: Trombiculidae) parasitizing cricetid rodents in Morro Grande Forest Reserve, São Paulo State, Brazil
}

\author{
Fernando de C. Jacinavicius ${ }^{1 \neq}=\left(\mathbb{C}^{\text {, Rafaela L. Arbex }}{ }^{1 \oplus}\right.$, Darci M. Barros-Battesti ${ }^{\circledR}$, Ricardo \\ Bassini-Silva ${ }^{1,2}$
}

${ }^{1}$ Laboratório de Coleções Zoológicas, Instituto Butantan, São Paulo, SP, Brazil. ${ }^{2}$ Departamento de Patologia, Reprodução e Saúde Única, Faculdade de Ciências Agrárias e Veterinárias-UNESP, Jaboticabal, SP, Brazil.

拝三”Corresponding author: fcjacinavicius@gmail.com

Edited by: Jose W. S. Melo (Guest Editor)

Received: November 04, 2021. Accepted: November 20, 2021. Published: December 08, 2021.

\begin{abstract}
Chigger mites are ectoparasites of terrestrial vertebrates and can even accidentally bite humans, causing lesions on their skins. The coparasitism is gradually being reported for this family, and recent studies have highlighted this relationship worldwide. In Brazil, only some records of chigger species co-parasitizing rodents and lizards in the Pernambuco and Piauí States were done. The present study reports six co-parasitism situations in cricetid rodents collected in the Morro Grande Forest Reserve, Cotia Municipality, São Paulo State, Brazil.
\end{abstract}

Keywords: Trombiculids, ectoparasites, Neotropical region, Rodentia.

Chigger mites (Trombidiformes: Trombiculidae s. I.) are ectoparasites of terrestrial vertebrates, such as amphibians, reptiles, birds, and mammals, as well as, these mites accidentally can bite humans, causing lesions in the skin host (Miyajima \& Okumura 1917; Shatrov 2000).

Many studies have been done on the taxonomy and systematics of chigger mites, but little is known about their ecology. The co-parasitism relationship exists for mites and is gradually being reported for this family as well. Although there are few records in literature (Goff 1979), recent studies have highlighted the co-parasitism within different species of chiggers around the world (Barnard et al. 2015; Moniuszko et al. 2018; Jacinavicius et al. 2019; 2021).

In Brazil, some co-parasitism cases were already reported for two states (Jacinavicius et al. 2019; 2021). In Pernambuco State, Pseudoschoengastia petrolinensis Jacinavicius, Bassini-Silva \& BarrosBattesti, 2019, Eutrombicula batatas (L., 1758) and Quadraseta falconensis Goff \& Brennan, 1977 parasitizing the same whiteeared opossum, Didelphis albiventris Lund, 1840 (Didelphimorphia: Didelphidae) and also, $P$. petrolinensis and $Q$. falconensis were collected again together in a second host of the same species, $D$. albiventris, in the same state (Jacinavicius et al. 2019). While in the state of Piauí, six cases of co-parasitism were reported, (1) Eutrombicula alfreddugesi (Oudemans, 1910), Microtrombicula brachytrichia Brennan, 1971, and Neoschoengastia ochoai Jacinavicius \& Bassini-Silva, 2021 were collected parasitizing the same Peters' lava lizard, Tropidurus hispidus (Spix, 1825) (Squamata: Tropiduridae); (2) Susa bauchani Jacinavicius \& Bassini-Silva, 2021 and Quadraseta welbourni Jacinavicius \& BassiniSilva, 2021 parasitizing the same São Lourenço Punare, Thrichomys laurentius Thomas, 1904 (Rodentia: Cricetidae); and three different situations of chiggers parasitizing an unidentified rodent of the genus Rhipidomys Tschudi, 1845 (Rodentia: Cricetidae), which occurred among Paraguacarus klompeni Jacinavicius \& Bassini-Silva, 2021 and M. brachytrichia; P. klompeni and Microtrombicula rhipidomysi Goff, Whitaker \& Dietz, 1983; and P. klompeni and P. petrolinensis (Jacinavicius et al. 2021).

The taxonomy chigger mites survey of Morro Grande Forest Reserve, Cotia Municipality, São Paulo State, Brazil, was previously reported by
Jacinavicius et al. (2015, 2018a, 2018b). However, the present study aims to show the co-parasitism observed between different chigger mite species collected from small mammals in the Morro Grande Forest Reserve. The Morro Grande Forest Reserve represents one of the most significant remnants of forests on the Planalto Paulistano (Metzger et al. 2006), extending from the Serra do Mar to the city of Campinas. The collections of the small mammals took place in two localities of this reserve, one close to the Pedro Beicht Dam ( $23^{\circ} 42^{\prime} 56^{\prime \prime} \mathrm{S} ; 46^{\circ} 57^{\prime} 29^{\prime \prime} \mathrm{W}$ )

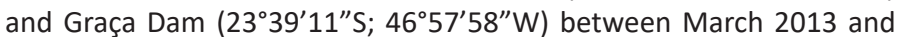
December 2015, during five days per month. All mites were collected and stored in $100 \%$ alcohol for further studies. Each host represented a collection event; thus, all collected mites were stored together to do the screening later.

The mites collected were sent to the Acarological Collection of Instituto Butantan (IBSP) to be slide-mounted and identified, following the preparations described by Barros-Battesti et al. (2021). For the chigger identification, we use the genera key made by Brennan \& Goff (1977) and the original descriptions of all species described in the identified genera.

At the end of the collection campaign, 72 hosts parasitized by mites were collected. They were 16 marsupials (Didelphimorphia: Didelphidae) - 10 Didelphis aurita (Wied-Neuwied, 1826); 1 Metachirus nudicaudatus (É. Geoffroy, 1803), and 5 Monodelphis americana (Müller, 1776); and 56 cricetid rodents (Rodentia: Cricetidae) - 32 Akodon montensis Thomas, 1913, 1 Delomys dorsalis (Hensel, 1873), 4 Delomys sublineatus (Thomas, 1903), 7 Euryoryzomys russatus (Wagner, 1848), 5 Holochilus brasiliensis (Desmarest, 1819), 1 Necromys lasiurus (Lund, 1840), 1 Nectomys squamipes (Brants, 1827), 1 Sooretamys angouya (Fischer, 1814), and 4 Thaptomys nigrita (Lichtenstein, 1830). Of which 35 hosts (5 marsupials and 30 cricetid rodent species) had been collected with chigger mites.

The co-parasitism was observed on six hosts examined. Four of them with two different chigger species, and the associations were: Quadraseta mirandae Goff \& Brennan, 1977 (IBSP 10606C) and Quadraseta pazca (Brennan \& Jones, 1964) (IBSP 10606B) parasitizing the same montane akodont, Akodon montensis Thomas, 1913 (Rodentia: Cricetidae) (Fig. 1A); Quadraseta trapezoides (Brennan 


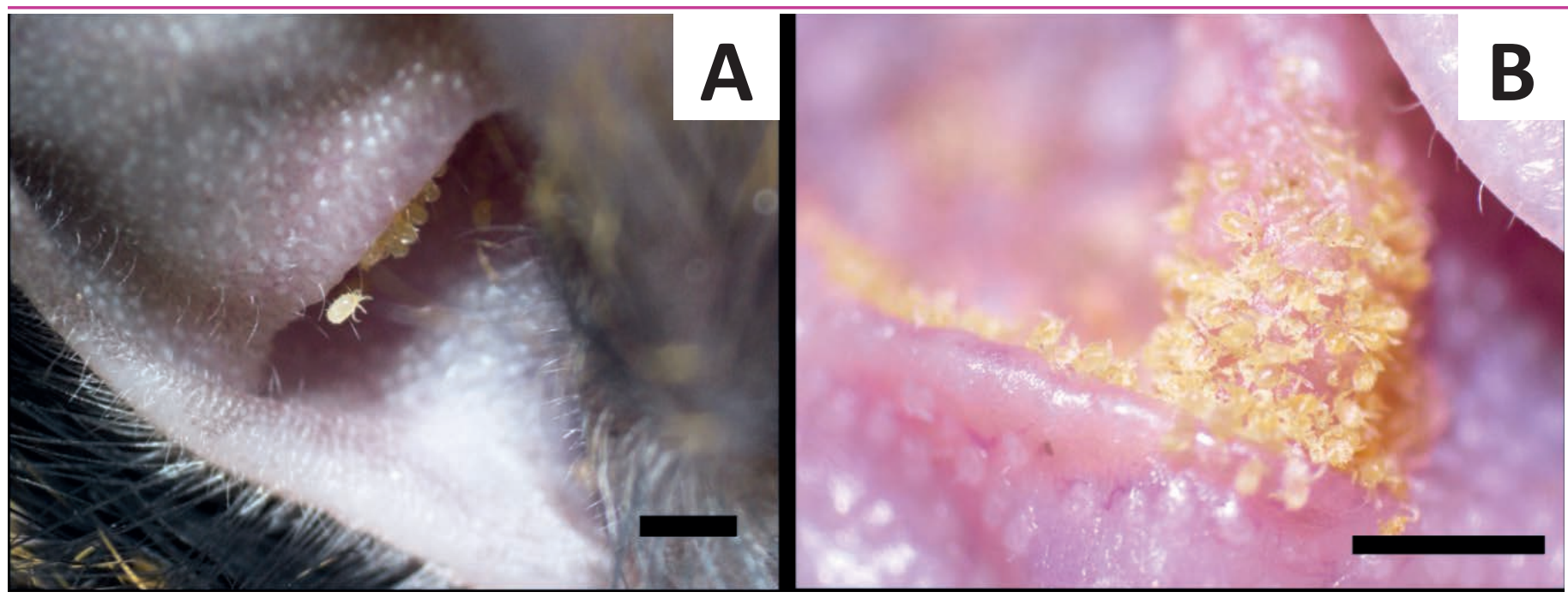

Figure 1. Chiggers attached to rodent host's ear. A. Larvae of Quadraseta spp. (Trombiculidae) on Akodon montensis Thomas, 1913 (Cricetidae). B. larvae of Quadraseta spp. on larvae Euryoryzomys russatus (Wagner, 1848) (Cricetidae). Scale bars: 1000 $\mu \mathrm{m}$.

\& Jones, 1964) (IBSP 11110C) and Quadraseta brasiliensis Goff \& Gettinger, 1989 (IBSP 11110E) parasitizing the same South American water rat, Nectomys squamipes (Brants, 1827) (Rodentia: Cricetidae); Trombewingia bakeri (Fonseca, 1955) (IBSP 11364A) and Speleocola tamarina Goff, Whitaker \& Dietz, 1987 (IBSP 11364B) parasitizing the same Sooretamys angouya (Fischer, 1814) (Rodentia: Cricetidae); and T. bakeri (IBSP 11369A) and Q. brasiliensis (IBSP 11369B) parasitizing the same striped Atlantic Forest rat, Delomys dorsalis (Hensel, 1873) (Rodentia: Cricetidae). A record of three different species that are Kymocta brasiliensis (Fonseca, 1936) (IBSP 11129C), Q. mirandae (IBSP 11129B), and a novel Kymocta Yunker \& Brennan, 1962 species (IBSP $11129 \mathrm{D})$ parasitizing another specimen of $A$. montensis. And finally, the same russet rice rat, Euryoryzomys russatus (Wagner, 1848) (Rodentia: Cricetidae), was collected parasitized with four different species of chigger mites, Quadraseta flochi Goff \& Brennan, 1977 (IBSP 11096F), Q. pazca (IBSP 11096E), Q. brasiliensis (IBSP $11096 \mathrm{G}$ ) and a novel Kymocta species (IBSP 11096D) (Fig. 1B). Of the marsupials examined, none were collected with more than one species of the chigger.

It is worth commenting that in all these collections, in addition to the chigger collections, ticks (Ixodida: Ixodidae), laelapid, and macronyssid mites (Mesostigmata: Lealapidae and Macronyssidae) were also collected.

During the field work, it was observed that the surroundings of the Morro Grande Forest Reserve are highly anthropogenic. The area receives considerable pressure due to the expansion of real estate and being constantly invaded for fishing and illegal hunting activities. The idea raised by Goff (1979) and Moniuszko et al. (2018) that coparasitism can happen due to anthropogenic pressure may be one of the causes of the present study.

On the other hand, a parasitic preference was observed, because each genus has been found in a different place on the host's body. The species of Quadraseta Brennan, 1970 were all found inside the host's ear. In contrast, Kymocta species were all intranasal, and T. bakeri was found parasitizing the ear edge region of the same hosts. In this way, it can be said that at least the co-parasitism observed in these hosts did not bring competition for space or food regarding genera competition. However, the Quadraseta species appear to compete among them, which was found up to three different species in one same host's ear. New studies must be carried out, and the co-parasitism reported. In this way, we can begin to understand the population dynamics and patterns of parasitism related to chiggers.

\section{Acknowledgments}

For their assistance with fieldwork, we thank Laerte Bento Viola, Valeria Castilho Onofrio, Diego Garcia Ramirez, Felipe Gomes Moreira dos Santos, Juliana Cuoco Badari, Jairo Alfonso Mendoza Roldan, Gabriel Alves Landulfo, Reinaldo Amaral Carneiro, and Leidiane Lima Duarte. For curatorial technical assistance and access at the collection
IBSP, we thank Gabrielle Ribeiro de Andrade, Maria Cristina Ferreira do Rosário, and Valeria Castilho Onofrio. This work was supported by Fundação de Amparo à Pesquisa do Estado de São Paulo (FAPESP no. 2017/01416-7, 2018/24667-8 and 2020/11755-6 to RB-S; 2019/198530 to FCJ; 2021/01964-0 to RLA), and by Conselho Nacional de Desenvolvimento Científico e Tecnológico (CNPq no. 454907/2014-1 to DMB-B, and $377976 / 2014-8$ to FCJ). This study was financed in part by the Coordenação de Aperfeiçoamento de Pessoal de Nível Superior Brasil (CAPES) - Finance Code 001.

\section{Authors' Contributions}

RLA collected the data of chiggers in co-association with the small mammals and prepared the material for examination. FCJ, RB-S, performed the study and confirmed the identification of the mites. RB$S, F C J, R L A$, and DMBB conducted the mite's preparations and wrote the manuscript.

\section{References}

Barros-Battesti, D. M.; Jacinavicius, F. C.; Bauchan, G.; Bassini-Silva, R. (2021) Chapter 24: Techniques for studies on Acariformes. In: Barros-Battesti, D. M.; Machado, R. Z.; André, M. R. (Eds.), Brazilian ectoparasite fauna of veterinary importance, Volume 1, Mite fauna of veterinary importance: Acariformes, pp. 294-303. Jaboticabal: CBPV.

Barnard, K.; Krasnov, R. B.; Goff, M. L.; Matthee, S. (2015) Infracommunity dynamics of chiggers (Trombiculidae) parasitic on a rodent. Parasitology, 142: 1605-1611. doi: 10.1017/S0031182015001110

Brennan, J. M.; Goff, M. L. (1977) Keys to the genera of chiggers of the Western Hemisphere (Acarina: Trombiculidae). Journal of Parasitology, 63(3): 554-566. doi: 10.2307/3280021

Goff, M. L. (1979) Host exploitation by chiggers (Acari: Trombiculidae) infesting Papua New Guinea land mammals. Pacific Insects, 20: 321-353.

Jacinavicius, F. C.; Bassini-Silva, R.; Brandão, M. V.; Hingst-Zaher, E.; Barros-Battesti, D. M. (2015) Trombewingia bakeri (Fonseca, 1955) (Trombidiformes: Trombiculidae): lectotype/paralectotype designations and new records. Systematic and Applied Acarology, 20: 641-646. doi: 10.11158/saa.20.6.6

Jacinavicius, F. C.; Bassini-Silva, R.; Mendoza-Roldan, J. A.; Munoz-Leal, S.; Hingst-Zaher, E.; Ochoa, R.; Bauchan, G. R.; Barros-Battesti, D. M. (2018b) A contribution to the knowledge of Quadraseta brasiliensis Goff and Gettinger, 1989 (Trombidiformes: Trombiculidae), with description of the deutonymph instar. Acarologia, 58: 442-456. doi: 10.24349/acarologia/20184252

Jacinavicius, F. C.; Bassini-Silva, R.; Mendoza-Roldan, J. A.; Pepato, A. R.; Ochoa, R.; Welbourn, C.; Barros-Battesti, D. M. (2018a) A checklist of chiggers from Brazil, including new records (Acari: 
Trombidiformes: Trombiculidae and Leeuwenhoekiidae). Zookeys, 743: 1-41. doi: 10.3897/zookeys.743.22675

Jacinavicius, F. C.; Bassini-Silva, R.; Oliveira, G. M. B.; Horta, M. C.; Welbourn, C.; Ochoa, R.; Barros-Battesti, D. M. (2019) Description of Pseudoschoengastia petrolinensis n. sp. (Trombidiformes: Trombiculidae), and new records of chiggers from northeastern Brazil. International Journal of Acarology, 45: 227-232. doi: 10.1080/01647954.2019.1601766

Jacinavicius F. C.; Bassini-Silva, R.; Huang-Bastos, M.; Horta, M. C.; Barros-Battesti, D. M. (2021) New species of chiggers (Trombidiformes: Trombiculidae and Leeuwenhoekiidae) from the conservation unit Parque Nacional da Serra das Confusões, Brazil. Journal of Medical Entomology, 58(1): 286-297. doi: 10.1093/jme/ tjaa178

Metzger, J. P.; Alves, L. F.; Goulart, W.; Teixeira, A. M. G.; Simões, S. J. C.; Catharino, E. L. M. (2006) Uma área de relevante interesse biológico, porém pouco conhecida: a Reserva Florestal do Morro Grande. Biota Neotropica, 6(2):1-33. doi: 10.1590/S167606032006000200003

Miyajima, M.; Okumura, T. (1917) On the life cycle of the akamushi carrier of Nippon river fever. Kitasato Archives of Experimental Medicine 1: 1-14.

Moniuszko, H.; Felska, M.; Mąkol, J. (2018) Evidence for co-invasion events: different chigger species (Actinotrichida, Trombidioidea: trombiculidae) share a host. Experimental and Applied Acarology, 76: 29-39. doi: 10.1007/s10493-018-0293-4

Shatrov, A. B. (2000) Trombiculid mites and their parasitism on vertebrate hosts. Trudy Zoologicheskogo Instituta, 285: 1-328. 